
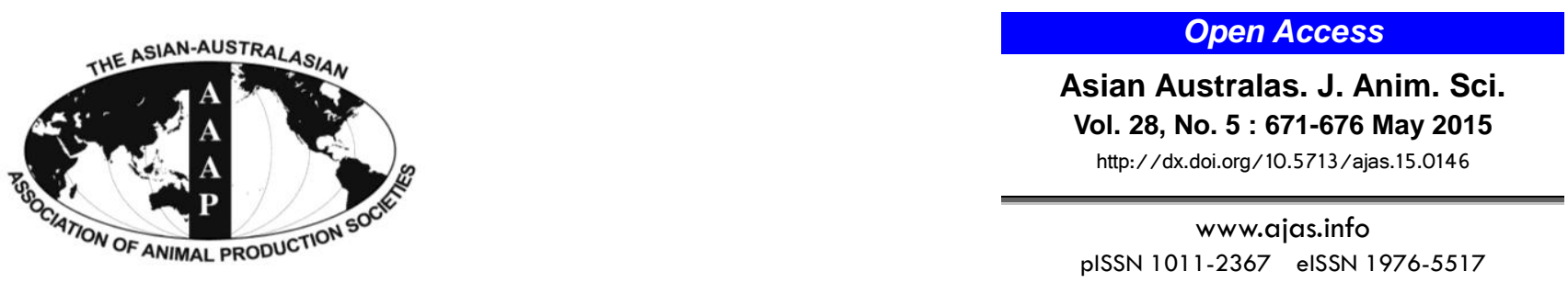

\title{
Effects of Ripening Duration and Rosemary Powder Addition on Salchichon Modified Sausage Quality
}

\author{
Jong-Hyun Jung ${ }^{1,2}$, Kwan-Seob Shim ${ }^{2}$, and Daekeun Shin ${ }^{3, *}$ \\ ${ }^{1}$ Department of Agricultural Biotechnology, Seoul National University, Seoul 151-921, Korea
}

\begin{abstract}
The ripening durations and ingredients for the Salchichon sausages were modified to increase pork rear leg consumption by Korean consumers. The salchichon, a ripened pork sausage, was produced to evaluate the efficacy of two different ripening durations with and without rosemary powder on salchichon sausage quality, and the treatments were: i) 45 days of ripening without rosemary, ii) 60 days of ripening without rosemary, iii) 45 days of ripening with $0.05 \%$ rosemary, and iv) 60 days of ripening with $0.05 \%$ rosemary. Significant differences were observed in both moisture and fat content for ripening durations, with the highest moisture and least fat content observed in salchichon modified sausage (SMS) ripened for 45 days. Ripening duration and rosemary addition appeared to influence water activity $\left(a_{w}\right)$ of salchichon sausages. The $a_{w}$ of SMS ripened for 45 days was 0.80 , whereas the other had $a_{w}$ values $<0.80$. Lactic acid bacteria were predominant, as Korean traditional fermented red pepper paste was added to sausages; however, the Bacillus cereus population was significantly affected by rosemary powder addition. Chewiness and gumminess decreased significantly due to the addition of rosemary powder compared to SMS without rosemary powder, and both 45 days of ripening and rosemary powder addition influenced the hardness of SMS. In conclusion, ripening duration of SMS for 45 days in the presence of rosemary powder provided superior SMS quality with an economical ripening duration compared to that of ripening with rosemary powder or ripening for 60 days. (Key Words: Salchichon Sausage, Ripening Duration, Rosemary, Lactic Acid Bacteria, Quality)
\end{abstract}

\section{INTRODUCTION}

Pork meat consumption per capita continues to expand as consumer income increases. However, the interest of Korean consumers for pork meat regions is limited, and strategies to increase consumption in non-preferred pork meat regions are necessary. The focus of the processed meat industry lies in producing higher value processed meat products from rarely favored pork meat regions, taking over $63 \%$ of the whole pork carcass (Seong et al., 2010; 2011). Fermentation/ripening of meat as well as adding naturally derived compounds including rosemary, plum and chitosan to meat products are ways to produce high profit processed

\footnotetext{
* Corresponding Author: Daekeun Shin. Tel: +82-33-248-2148, Fax: +82-33-248-2142, E-mail: aceflavor@ hotmail.com

2 Department of Animal Biotechnology, Chonbuk National University, Jeonju 561-756, Korea.

${ }^{3}$ Department of Food Science and Nutrition, Hallym University, Chuncheon 200-702, Korea.

Submitted Feb. 17, 2015; Revised Mar. 17, 2015; Accepted Mar. 23, 2015
}

meat products and increase their nutritional values (Georgantelis et al., 2007; Nunez et al., 2008). Among them, fermentation/ripening of meat is used to improve flavor, color and texture and is dependent on biochemical and microbiological transformations of proteins and lipids in the meat (Lizaso et al., 1999; Beriain et al., 2000a). Lactic acid bacteria (LAB), which generates acid due to the metabolic reaction of the LAB with sugar, are the primary bacteria inoculated as a starter culture for meat fermentation (Coppola et al., 1998; Papamanoli et al., 2003). As highly activated proteolytic enzymes, LABs degrade proteins and peptides, contributing to the overall flavor and texture of fermented meat products (Benito et al., 2007).

Salchichon is a typical dry cured sausage that originated in Spain. The use of a LAB starter culture is unusual in salchichon production, and traditional preparation is often limited to adding black pepper without other typical sausage additives such as garlic or paprika (Beriain et al., 2000a,b). As a result, changes in traditional salchichon production during ripening are influenced by the raw

Copyright $@ 2015$ by Asian-Australasian Journal of Animal Sciences This is an open-access article distributed under the terms of the Creative Commons Attribution Non-Commercial License (http://creativecommons.org/licenses/by-nc/3.0/), which permits unrestricted non-commercial use, distribution, and reproduction in any medium, provided the original work is properly cited. 
materials as well as the processing environment (Beriain et al., 2000a; Fernandez-Lopez et al., 2008; Lorenzo et al., 2012). However, a recent study examined inoculation of sausages with LAB and reported on the microbiological safety of the practice (Benito et al., 2007). The number of $\mathrm{LAB}$ during ripening duration is the key process in sausage quality and appears to be important for modifying salchichon characteristics. In addition, our preliminary study conducted to manage salchichon ripening with LAB showed that predominant LAB was confirmed when Korean Traditional Fermented Red Pepper Paste (KFRP) was applied with the aim of improving the number of LAB and providing an environment for LAB growth on salchichon modified sausage (SMS, data not shown). Fermentation/ripening are regulated by the predominant microorganisms in the meat and are therefore time dependent.

The main purposes of this study were to establish the most effective ripening period and also to examine the influence of rosemary powder on LAB and growth of other microbe, by increasing LAB competition with other bacteria in SMS. As results, salchichon sausage modification may generate the intention of improving the economic value of pork rear leg within the Korean and East Asian market by minimizing ripening duration.

\section{MATERIALS AND METHODS}

\section{Sausage formulation and preparation}

The traditional salchichon formulation was modified to produce Korean style SMS. A total of 3,200 g rear leg lean pork and 1,600 g pork back fat were coarsely ground through a $0.32 \mathrm{~cm}$ plate for each treatment. The $4 \mathrm{~kg}$ coarsely ground mixture was combined in a 7:3 ratio of lean pork and pork back fat and was then mixed with $50 \mathrm{~g} / \mathrm{kg}$ water, $20 \mathrm{~g} / \mathrm{kg}$ sodium chloride, $0.2 \mathrm{~g} / \mathrm{kg}$ sodium nitrite, 40 $\mathrm{g} / \mathrm{kg}$ KFRP, $10 \mathrm{~g} / \mathrm{kg}$ onion powder and $10 \mathrm{~g} / \mathrm{kg}$ ginger powder. The KFRP was added to increase the LAB population and to minimize the traditional pork odor. Five $\mathrm{g} / \mathrm{kg}$ rosemary powder was included depending on the treatment, which anticipated decreasing non-profitable micro-organism growth in the SMS during ripening. The mixture was re-ground and stuffed into a natural hog casing 62 to $65 \mathrm{~mm}$ in diameter. The SMS of approximately $30 \mathrm{~cm}$ in length was stored and ripened in a drying chamber at $22^{\circ} \mathrm{C}$ and $90 \%$ relative humidity (RH) for 2 days, followed by 43 or 58 days of dry-curing at $12^{\circ} \mathrm{C}$ and $65 \%$ to $70 \% \mathrm{RH}$. The SMS treatments were as follows: i) salchichon ripened for 45 days without rosemary powder (ROR45), ii) salchichon ripened for 60 days without rosemary powder (ROR60), iii) salchichon ripened for 45 days with rosemary powder (RWR45), and iv) salchichon ripened for 60 days with rosemary powder (RWR60). The four SMS per treatments underwent chemical and physico-chemical analysis to determine the effects of ripening duration and adding rosemary. Due to economic reasons, the microbiological properties of SMS were evaluated on ROR45 and RWR45 only.

\section{Chemical analysis}

Moisture, crude fat, crude protein and crude ash content were determined by oven-drying, soxhlet, kjeldahl and dry ashing methods, respectively (AOAC \#934.01, 954.08, 984.13 and 900.02, respectively) (AOAC, 1995). All results are reported as percentages $(\%)$.

\section{Physico-chemical analysis}

Ten g samples were homogenized with $90 \mathrm{~mL}$ of double distilled water for $30 \mathrm{~s}$ at 13,500 rpm (T25B, IKA Sdn. Bhd., Staufen, Germany). A pH meter (Orion 420A+, Thermo Electron Co., Beverly, MA, USA) was calibrated using a standard buffer at $\mathrm{pH}$ 7.0, and duplicate readings were taken on each sample, and the average was reported.

Commission Internationale de l'Eclairage (CIE) L* (lightness), $\mathrm{a}^{*}$ (redness) and $\mathrm{b}^{*}$ (yellowness) color space values were determined using a Minolta colorimeter (Minolta Chroma Meter CR-300, Minolta Co., Ltd, Ramsey, NJ, USA). The colorimeter was calibrated using a white tile $(\mathrm{Y}=92.8, \mathrm{x}=0.3134, \mathrm{y}=0.3193)$. Triple readings were performed for each sample, and all results were averaged. Average values are expressed as CIE L*, a* and $b^{*}$ color space values.

Water activity $\left(a_{w}\right)$ of the SMS samples was determined at $25^{\circ} \mathrm{C}$ using a Thermoconstanter $a_{w}$ Sprint Novasina TH500 (Novasina, Axair Ltd., Pfaeffikon, Switzerland), and the average values of eight samples per treatment are reported.

Texture properties were measured using the modified method of Kealy (2006). All SMS samples were warmed, and six different cubes $\left(1 \mathrm{~cm}^{3}\right)$ were shaped and placed on a texture analyzer (TA-XT Express, Stable Micro System, Surrey, England). This procedure was used to determine adhesiveness, chewiness, cohesiveness, gumminess, hardness and springiness. The texture analyzer, equipped with a cylindrically shaped plunger ( $5 \mathrm{~mm}$ diameter), was operated at a $2 \mathrm{~mm} / \mathrm{sec}$ pre-test speed, $1 \mathrm{~mm} / \mathrm{s}$ test speed and $2 \mathrm{~mm} / \mathrm{s}$ post-test speed. All sample areas were averaged and expressed as adhesiveness ( $\mathrm{N} \mathrm{s})$, chewiness $(\mathrm{N} \mathrm{mm})$, cohesiveness (\%), gumminess $(\mathrm{N})$, hardness $(\mathrm{N})$ and springiness $(\mathrm{mm})$.

\section{Microbiological analysis}

Only $25 \mathrm{~g}$ of the ROR45 and RWR45 crude homogenate samples were prepared after the first and last slices of SMS were discarded due to economic reasons. The samples were added to $225 \mathrm{~mL}$ autoclaved peptone water and 
homogenized using a stomacher (Stomacher 400, Seward, England) for $2 \mathrm{~min}$. One $\mathrm{mL}$ of the homogenized sample was used for serial dilutions. Appropriate dilutions were made in triplicate for total plate count (TPC, $200 \mu \mathrm{L}$ ) and LAB $(100 \mu \mathrm{L})$ on Plate Count Agar (PCA, Difco, Bectone Dickinson, Sparks, MD, USA) and de Man Rogosa and Sharpe Agar with bromophenol blue. All plates were incubated at $37^{\circ} \mathrm{C}$ for 24 to $72 \mathrm{~h}$. TPC and LAB were counted and reported as log colony-forming unit (CFU)/g.

Only ROR45 and RWR45 SMS were used for Bacillus cereus, E. coli and E. coli O157:H7, Listeria monocytogenes and Salmonella spp. as mentioned before. All ROR45 and RWR45 SMS samples were homogenized with $225 \mathrm{~mL}$ phosphate-buffered dilution water, Escherichia coli broth, UVM-modified Listeria, peptone water or tryptic soy broth, respectively and then incubated at $30^{\circ} \mathrm{C}$ to $37^{\circ} \mathrm{C}$ for $24 \mathrm{~h}$. The incubated samples were streaked on MannitolEgg Yolk Polymyxin Agar, Eosin Methylene Blue, SMAC, Oxford Agar, Xylose, Lysine, Deoxycholate, and Mannitol Salt Agar, respectively, and all streaked plates were reincubated at $30^{\circ} \mathrm{C}$ to $37^{\circ} \mathrm{C}$ for 24 to $48 \mathrm{~h}$. Colonies of Bacillus cereus, E. coli, and E. coli O157:H7, Listeria monocytogenes, Salmonella spp. and Staphylococcus aureus were isolated and confirmed using the Vitek BCL system (bioMerieux, Marcy I'Etoile, France) for B. cereus, the Vitek GN+ (bioMerieux, Marcy I'Etoile, France) for E. coli. as well as Salmonella spp., and S. aureus, or the Vitek GP+ for L. monocytogenes (bioMerieux, Marcy I'Etoile, France). A serum test was further conducted on E. coli $\mathrm{O} 157: \mathrm{H} 7$ for confirmation, in accordance with Vitek GN+.

\section{Statistical analysis}

All data were analyzed as a $2 \times 2$ factorial arrangement by analysis of variance using the generalized linear model (GLM) procedure in SAS software ver. 6.12 (SAS, 1998). A $\mathrm{p}<0.05$ was considered significant.

\section{RESULTS AND DISCUSSION}

\section{Proximate composition of SMS}

Table 1 shows the proximate composition of SMS ripened for 45 or 60 days, with or without rosemary powder. The moisture content of SMS was influenced by ripening duration, and the potential for water leakage increased as autolysis advanced during the ripening process. HuffLonergan and Lonergan (2005) and Kristensen and Purslow (2001) reported that protein oxidation, which occurs during aging, causes intra- and/or inter-protein disulfide cross-links of the calpain histidine and cysteine residues as well as degradation of vinculin and desmin. Despite calpain inactivation and vinculin or desmin degradation, autolysis and myofibril shrinkage may not be prevented completely, but water holding ability of myofibrils is negatively
Table 1. Proximate composition of salchichon modified sausages after 45 or $60 \mathrm{~d}$ of ripening and/or added rosemary powder

\begin{tabular}{lcccc}
\hline Treatment & Moisture & Crude fat & $\begin{array}{c}\text { Crude } \\
\text { protein }\end{array}$ & Ash \\
\hline p-value & & & & \\
$\quad$ Dayxrosemary & 0.48 & 0.95 & 0.85 & 0.25 \\
$\quad$ Day & 0.01 & 0.04 & 0.88 & 0.85 \\
$\quad$ Rosemary & 0.02 & 0.24 & 0.83 & 0.86 \\
Day & & & & \\
$\quad 45$ & $24.77^{\mathrm{a}}$ & $26.33^{\mathrm{b}}$ & 44.14 & 4.76 \\
60 & $20.06^{\mathrm{b}}$ & $30.81^{\mathrm{a}}$ & 44.44 & 4.70 \\
SEM & 0.55 & 1.19 & 1.30 & 0.18 \\
Rosemary & & & & \\
$\quad$ Rosemary (w/o) & $21.12^{\mathrm{b}}$ & 29.68 & 44.50 & 4.71 \\
$\quad$ Rosemary & $23.71^{\mathrm{a}}$ & 27.46 & 44.08 & 4.75 \\
$\quad$ SEM & 0.55 & 1.19 & 1.29 & 0.18 \\
\hline
\end{tabular}

SEM, standard error of the mean $(n=4)$.

a,b Mean values within a column followed by different letters are significantly different $(\mathrm{p}<0.05)$.

influenced by protein oxidation. Therefore, water retention by myofibrillar protein can be lost easily during ripening, as about $85 \%$ of the total water in pork is entrapped (Estevez et al., 2011). As results, more water was lost with longer ripening periods (Eim et al., 2008), although rosemary appeared to ameliorate water retention due to its antioxidant activity (Estevez and Cava, 2006; Shin, 2006). The antioxidant activity of rosemary powder for protein degradation moderated the loss of sulfhydryl groups and the generation of carbonyl compounds and then maintained water holding ability while equivalent ripening duration was applied to the SMS (Estevez et al., 2005; 2011). The 60 day SMS contained less water, whereas crude fat content was significantly lower in the 45 day SMS than that in the 60 day SMS. Fat contents of 45 and 60 day SMS were $26.33 \%$ and $30.81 \%$, respectively. These results coincided with a similar study that found a negative relationship between water and fat content in salmon (Morkore et al., 2001).

\section{pH, color and water activity of salchichon}

No effect on CIE surface color $\mathrm{L}^{*}, \mathrm{a}^{*}$, and $\mathrm{b}^{*}$ of the SMS was observed; however, significant effects on $\mathrm{pH}$ and water activity were observed as a result of ripening and/or adding rosemary powder $(\mathrm{p}<0.05)$ (Table 2). The SMS ripened for 60 days had higher $\mathrm{pH}$ values (pH6.70) compared to SMS aged for 45 days. The higher $\mathrm{pH}$ was likely due to enzymatic and/or microbial protein degradation, which generates ammonia and amine as byproducts (Maijala et al., 1995; Hughes et al., 2002). Demeyer (1982) observed that the drying process induces the release of ammonia in sausage meat, thereby raising the $\mathrm{pH}$ of sausages ripened for an extended period. Rosemary powder had no effect on $\mathrm{pH}$. Water activity, an important 
Table 2. $\mathrm{pH}$, color and water activity of salchichon modified sausage after 45 or $60 \mathrm{~d}$ ripening and/or added rosemary powder

\begin{tabular}{|c|c|c|c|c|c|}
\hline \multirow{2}{*}{ Treatment } & \multirow{2}{*}{$\mathrm{pH}$} & \multicolumn{3}{|c|}{ CIE color space } & \multirow{2}{*}{$a_{w}$} \\
\hline & & L*(Lightness) & $\mathrm{a}^{*}$ (Redness) & $\mathrm{b}^{*}($ Yellowness $)$ & \\
\hline \multicolumn{6}{|l|}{$\overline{p \text {-value }}$} \\
\hline Dayxrosemary & 0.72 & 0.95 & 0.61 & 0.36 & 0.21 \\
\hline Day & 0.01 & 0.05 & 0.50 & 0.57 & 0.01 \\
\hline Rosemary & 0.51 & 0.87 & 0.13 & 0.67 & 0.01 \\
\hline \multicolumn{6}{|l|}{ DAY } \\
\hline 45 & $6.40^{\mathrm{b}}$ & 32.19 & 11.86 & 10.12 & $0.80^{\mathrm{a}}$ \\
\hline 60 & $6.70^{\mathrm{a}}$ & 33.85 & 13.08 & 10.55 & $0.74^{\mathrm{b}}$ \\
\hline SEM & 0.04 & 0.49 & 0.60 & 0.50 & 0.01 \\
\hline \multicolumn{6}{|l|}{ Rosemary } \\
\hline Rosemary (w/o) & 6.57 & 33.08 & 13.23 & 10.17 & $0.76^{\mathrm{b}}$ \\
\hline Rosemary & 6.53 & 32.95 & 11.71 & 10.49 & $0.78^{\mathrm{a}}$ \\
\hline SEM & 0.04 & 0.49 & 0.60 & 0.50 & 0.01 \\
\hline
\end{tabular}

CIE, Commission Internationale de l'Eclairage; SEM, standard error of the mean $(n=4)$. $a_{w}$, water activity.

${ }^{\mathrm{a}, \mathrm{b}}$ Mean values within a column followed by different letters are significantly different $(\mathrm{p}<0.05)$.

factor for microorganism growth, was significantly higher in SMS ripened for 45 days and added rosemary powder than that in the other SMSs, which contrasted with results by Hughes et al. (2002).

\section{Microbiological analysis of salchichon}

Only the SMS ripened for 45 days was tested for economic reasons. The ROR45 and RWR45 sausages were incubated to evaluate TPC and LAB (Table 3 ) as well as to test B. cereus, E. coli, E. coli O157:H7, L. monocytogenes, Salmonella spp. and S. aureus growth (Table 4). TPC and LAB counts did not differ significantly between the two conditions. $\mathrm{LAB}$ was the predominant microorganism in the sausages due to the addition of KFRP, as reported in previous studies (Roig-Sagues et al., 1999; Andrade et al., 2010). Andrade et al. (2010) postulated that inoculating

Table 3. Quantitative evaluation of total plate, coliform, and lactic acid bacteria counts in salchichon modified sausage after $45 \mathrm{~d}$ ripening and/or added rosemary powder

\begin{tabular}{lcc}
\hline \multirow{2}{*}{ Treatment } & \multicolumn{2}{c}{ Microorganisms $(\log$ cfu/g) } \\
\cline { 2 - 3 } & Total plate count & Lactic acid bacteria \\
\hline ROR45 & 7.70 & 7.55 \\
RWR45 & 7.79 & 7.69 \\
SEM $^{1}$ & 0.18 & 0.29 \\
\hline
\end{tabular}

ROR45, 45 days ripening without rosemary; RWR45, 45 days ripening with rosemary; SEM, standard error of the mean $(n=4)$.
LAB during the initial stage of salchichon production is important and that the salchichon LAB count surpasses $10^{7}$ CFU/g near the end of the ripening stage. Similar LAB counts were observed in the ROR45 and RWR45 treatments due to the addition of KFRP to the SMS. However, no effect on LAB growth was observed after adding rosemary powder to the SMS (Georgantelis et al., 2007). B. cereus, a frequent bacterium in fermented meat products, was the only bacteria observed (Table 4). As Spanish fermented sausages are comprised of up to $10 \%$ spices, these sausages can house large numbers of B. cereus spores (Encinas et al., 1996). B. cereus appears capable of surviving during 45 days of ripening, as it was identified in the SMS. However, $B$. cereus was not found in RWR45, which may have been be due to the antimicrobial activity of rosemary against $B$. cereus, as stated by Genena et al. (2008). Based on the results, adding rosemary powder to SMS increases microbial safety but not LAB.

\section{Texture properties of salchichon}

Results for the SMS textual properties analysis are shown in Table 5. Adhesiveness and springiness were not influenced by either the ripening period or rosemary powder $(\mathrm{p}>0.05)$. Both chewiness and gumminess, which seem to be related to hardness of SMS, decreased with added rosemary $(\mathrm{p}>0.05)$. Therefore, rosemary powder addition generated less harder SMS in contrast to similar cohesive

Table 4. Qualitative evaluation for Bacillus cereus, Escherichia coli, Listeria monocytogenes, Salmonella spp. and Staphylococcus aureus in salchichon modified sausage after $45 \mathrm{~d}$ ripening and/or added rosemary powder

\begin{tabular}{lcccccc}
\hline Treatment & Bacillus cereus & Escherichia coli & $\begin{array}{c}\text { Escherichia coli } \\
\text { O157:H7 }\end{array}$ & $\begin{array}{c}\text { Listeria } \\
\text { monocytogenes }\end{array}$ & $\begin{array}{c}\text { Salmonella spp. } \\
\text { Staphylococcus } \\
\text { aureus }\end{array}$ \\
\hline ROR45 & + & - & - & - & - & - \\
RWR45 & - & - & - & - & - & - \\
\hline
\end{tabular}

ROR45, 45 days ripening without rosemary; RWR45, 45 days ripening with rosemary.

+ , detected; -, not detected $(n=4)$. 
Table 5. Texture properties of salchichon modified sausage after 45 or $60 \mathrm{~d}$ ripening and/or added rosemary powder

\begin{tabular}{|c|c|c|c|c|c|c|}
\hline Treatment & $\begin{array}{c}\text { Adhesiveness } \\
(\mathrm{N} \mathrm{s})\end{array}$ & $\begin{array}{c}\text { Chewiness } \\
(\mathrm{N} \mathrm{mm})\end{array}$ & $\begin{array}{c}\text { Cohesiveness } \\
(\%)\end{array}$ & $\begin{array}{l}\text { Gumminess } \\
(\mathrm{N})\end{array}$ & $\begin{array}{l}\text { Hardness } \\
(\mathrm{N})\end{array}$ & $\begin{array}{c}\text { Springiness } \\
(\mathrm{mm})\end{array}$ \\
\hline \multicolumn{7}{|l|}{ p-value } \\
\hline Dayxrosemary & 0.26 & 0.13 & 0.06 & 0.17 & 0.45 & 0.97 \\
\hline Day & 0.12 & 0.30 & 0.01 & 0.07 & 0.01 & 0.21 \\
\hline Rosemary & 0.18 & 0.01 & 0.71 & 0.01 & 0.01 & 0.46 \\
\hline \multicolumn{7}{|l|}{ Day } \\
\hline 45 & 1.13 & 3.88 & $0.21^{\mathrm{a}}$ & 4.22 & $19.25^{\mathrm{b}}$ & 0.95 \\
\hline 60 & 0.68 & 4.58 & $0.16^{\mathrm{b}}$ & 5.70 & $37.66^{\mathrm{a}}$ & 0.84 \\
\hline SEM & 0.18 & 0.43 & 0.01 & 0.47 & 1.54 & 0.05 \\
\hline \multicolumn{7}{|l|}{ Rosemary } \\
\hline Rosemary (w/o) & 1.09 & $5.47^{\mathrm{a}}$ & 0.19 & $6.42^{\mathrm{a}}$ & $37.67^{\mathrm{a}}$ & 0.87 \\
\hline Rosemary & 0.71 & $2.99^{\mathrm{b}}$ & 0.18 & $3.49^{\mathrm{b}}$ & $19.23^{\mathrm{b}}$ & 0.93 \\
\hline SEM & 0.18 & 0.43 & 0.01 & 0.47 & 0.01 & 0.05 \\
\hline
\end{tabular}

SEM, standard error of the mean $(n=4)$.

${ }^{\mathrm{a}, \mathrm{b}}$ Mean values within a column followed by the different letter are significantly different $(\mathrm{p}<0.05)$.

SMS textures. Due to the ripening process of the SMS, protein oxidation generally leads to loss of protein functionality, triggering a harder external surface of the SMS structure through loss of water (Kristensen and Purslow, 2001; Huff-Lonergan and Lonergan, 2005). The water generating moisturized sausages were retained longer when rosemary powder was added to the SMS (Table 1). Hence, it seemed that rosemary powder had a protective effect on sausage structure, as it reduces hardness of the SMS external surface by delaying structural degradation and preventing water depletion on the external surface (Estevez and Cava, 2006; Estevez et al., 2006; Estevez et al., 2011). The hardness of SMS significantly increased when ripening duration was increased from 45 to 60 days $(\mathrm{p}<0.05)$.

\section{CONCLUSION}

The present study was conducted to determine the effects of ripening duration or adding rosemary powder on SMS. Increased moisture and less crude fat were observed with 45 days ripening compared to those at 60 days. Significantly lower $\mathrm{pH}$, improved water activity and analogous microbial numbers were obtained by reducing the ripening period to 45 days. The rosemary powder also ameliorated B. cereus counts and chewiness, gumminess and hardness of the SMS. These results indicate that both ripening for 45 days and rosemary powder addition seem to improve the quality of SMS and could generate high SMS profits, but further studies including a consumer sensory evaluation are required.

\section{REFERENCES}

Andrade, M. J., J. J. Cordoba, E. M. Casado, M. G. Cordoba, and M. Rodriguez. 2010. Effect of selected strains of
Debaryomyces hansenii on the volatile compound production of dry fermented sausage "salchichon". Meat Sci. 85:256-264. AOAC. 1995. Official Methods of Analysis. 15th ed., Association of Official Analytical Chemists, Washington DC, USA.

Benito, M. J., A. Martin, E. Aranda, F. Perez-Nevado, S. RuizMoyano, and M. G. Cordoba. 2007. Characterization and selection of autochthonous lactic acid bacteria isolated from traditional Iberian dry-fermented salchichon and chorizo sausages. J. Food Sci. 72:M193-201.

Beriain, M. J., J. Chasco, and G. Lizaso. 2000a. Relationship between biochemical and sensory quality characteristics of different commercial brands of salchichon. Food Control 11:231-237.

Beriain, M. J., G. Lizaso, and J. Chasco. 2000b. Free amino acids and proteolysis involved in 'salchichon' processing. Food Control 11:41-47.

Coppola, R., B. Giagnacovo, M. Lorizzo, and L. Grazia. 1998. Characterization of lactobacilli involved in the ripening of soppressata molisana, a typical southern Italy fermented sausage. Food Microbiol. 15:347-353.

Demeyer, D. I. 1982. Stoichiometry of dry sausage fermentation. Antonie van Leeuwenhoek 48:414-416.

Eim, V. S., S. Simal, C. Rossello, and A. Femenia. 2008. Effects of addition of carrot dietary fibre on the ripening process of a dry fermented sausage (sobrassada). Meat Sci. 80:173-182.

Encinas, J. P., J. Sanz-Gomez, M-L. Garcia-Lopez, M-R. GarciaArmesto, and A. Otero. 1996. Evaluation of different systems for the identification of Bacillus strains isolated from Spanish fermented sausages. Meat Sci. 42:127-131.

Estevez, M. and R. Cava. 2006. Effectiveness of rosemary essential oil as an inhibitor of lipid and protein oxidation: Contradictory effects in different types of frankfurters. Meat Sci. 72:348-355.

Estevez, M., S. Ventanas, and R. Cava. 2005. Protein oxidation in frankfurters with increasing levels of added rosemary essential oil: Effect on color and texture deterioration. J. Food Sci. 70:C427-C432.

Estevez, M., S. Ventanas, and R. Cava. 2006. Effect of natural and synthetic antioxidants on protein oxidation and colour and texture changes in refrigerated stored porcine live pate. Meat 
Sci. 74:396-403.

Estevez, M., S. Ventanas, M. Heinonen, and E. Puolanne. 2011. Protein carbonylation and water-holding capacity of pork subjected to frozen storage: Effect of muscle type, premincing, and packaging. J. Agric. Food Chem. 59:5435-5443.

Fernandez-Lopez, J., E. Sendra, E. Sayas-Barbera, C. Navrro, and J. A. Perez-Alvarez. 2008. Physico-chemical and microbiological profiles of "salchichon" (Spanish dryfermented sausage) enriched with orange fiber. Meat Sci. 80:410-417.

Genena, A. K., H. Hense, A. Jr. Smania, and S. M. de Souza. 2008. Rosemary - a study of the composition, antioxidant and antimicrobial activities of extracts obtained with supercritical carbon dioxide. Food Sci. Technol. 28:463-469.

Georgantelis, D., I. Ambrosiadis, P. Katikou, G. Blekas, and S. A. Georgakis. 2007. Effect of rosemary extract, chitosan and $\alpha$ tocopherol on microbiological parameters and lipid oxidation of fresh pork sausages stored at $4^{\circ} \mathrm{C}$. Meat Sci. 76:172-181.

Huff-Lonergan, E. and S. M. Lonergan. 2005. Mechanisms of water-holding capacity of meat: The role of postmortem biochemical and structural changes. Meat Sci. 71:194-204.

Hughes, M. C., J. P. Kerry, E. K. Arend, P. M. Kenneally, P. L. H. McSweeney, and E. E. O'Neill. 2002. Characterization of proteolysis during the ripening of semi-dry fermented sausages. Meat Sci. 62:205-216.

Kealy T. 2006. Application of liquid and solid rheological technologies to the textural characterization of semi-solid foods. Food Res. Int. 39:265-276.

Kristensen, L. and P. Purslow. 2001. The effect of ageing on the water-holding capacity of pork: role of cytoskeletal proteins. Meat Sci. 58:17-23.

Lizaso, G., J. Chasco, and M. J. Beriain. 1999. Microbiological and biochemical changes during ripening of salchichon a Spanish dry cured sausage. Food Microbiol. 16:219-228.

Lorenzo, J. M., S. Temperan, R. Bermudez, N. Cobas, and L. Purrinos. 2012. Changes in physico-chemical, microbiological, textural and sensory attributes during ripening of dry-cured foal salchichon. Meat Sci. 90:194-198.
Maijala, R., S. Eerola, S. Lievonen, P. Hill, and T. Hirvi. 1995. Formation of biogenic amines during ripening of dry sausages as affected by starter culture and thawing time of raw materials. J. Food Sci. 60:1187-1190.

Morkore, T., J. L. Vallet, M. Cardinal, M. C. Gomez-Guillen, P. Montero, O. J. Torrisen, R. Nortvedt, S. Sigurgisladottir, and M. S. Thomassen. 2001. Fat content and fillet shape of Atlantic salmon: relevance for processing yield and quality of raw and smoked products. J. Food Sci. 66:1348-1354.

Nunez de Gonzalez, M. T., R. M. Boleman, R. K. Miller, J. T. Keeton, and K. S. Rhee. 2008. Antioxidant properties of dried plum ingredients in raw and precooked pork sausage. J. Food Sci. 73:H63-H71.

Papamanoli, E., N. Tzanetakis, E. Litopoulou-Tzanetaki, and P. Kotzekidou. 2003. Characterization of lactic acid bacteria isolated from a Greek dry-fermented sausage in respect of their technological and probiotic properties. Meat Sci. 65:859-867.

Roig-Sagues, A. X., M. M. Hernandez-Herrero, E. I. LopezSabater, J. J. Rodriguez-Jerez, and M. T. Mora-Ventura. 1999. Microbiological events during the elaboration of "fuet", a Spanish ripened sausage. Eur. Food Res. Technol. 209:108-112.

SAS, 1998. SAS/STAT Software for PC Release 6.12. SAS Institute Inc., Cary, NC. USA.

Seong, P-N., J-H. Kim, S-H. Cho, D-W. Kang, G-H. Kang, B-Y. Park, J-M. Lee, J-H. Jung, and D-H. Kim. 2010. The effects of salt and $\mathrm{NaNO}_{2}$ on fatty acid composition, free amino acids, microbial counts and sensory characteristics of dry-cured ham processed under Korean environment. Korean J. Food Sci. Anim. Res. 30:435-442.

Seong, P-N., S-H. Cho, G-H. Kang, J-H. Kim, B-Y. Park, D. Jeong, B-K. Kim, J-H. Jung, S-G. Jeong, and D-H. Kim. 2011. The effects of salt levels and drying period on physicochemical and sensory parameters of dry-cured ham ripened in controlled condition. Korean J. Food Sci. Anim. Res. 31:914-920.

Shin, D. 2006. Antioxidant, Color and Sensory Properties of Sorghum Bran Pre-cooked Ground Beef Patties Varying in Fat and Iron Content. Master Thesis of Department of Food Science Texas A\&M University, College Station, TX, USA. 